\title{
A Convenient Lactic Dehydrogenase-Coupled Assay for Determining Pyridoxal 5'-Phosphate in Plasma
}

\author{
Stephen T. Worland ${ }^{1}$ and Jules A. Shafer ${ }^{2}$ \\ Department of Biological Chemistry, The University of Michigan Medical School, \\ Ann Arbor, Michigan 48109
}

Received September 4, 1979

\begin{abstract}
An assay for determining the concentration of pyridoxal 5'-phosphate in plasma from $0.4 \mathrm{ml}$ whole blood is reported. The assay consists of incubating deproteinized plasma with D-serine apodehydratase from Escherichia coli in $0.5 \mathrm{M} \mathrm{N}$-2-hydroxyethylpiperazine- $N^{\prime}-3$-propanesulfonic acid, $\mathrm{pH} 7.8$, at $37^{\circ} \mathrm{C}$ for $15 \mathrm{~min}$, and then determining the D-serine dehydratase activity of an aliquot of the incubation mixture. A lactic dehydrogenase-coupled assay (at $25^{\circ} \mathrm{C}$ ) was used to measure the rate of enzymically catalyzed conversion of $D$-serine to pyruvate, wherein depletion of NADH was followed continuously at $340 \mathrm{~nm}$. The concentration of pyridoxal 5'-phosphate in the plasma sample was estimated from the enzymic activity which is a linear function of the amount of pyridoxal 5 '-phosphate present in the assay.
\end{abstract}

Inadequate vitamin $B_{6}$ nutrition in laboratory animals and humans may cause serious abnormalities such as arteriosclerotic lesions (1), convulsions $(2,3)$, sideroblastic anemia (4), neuropathy (5), and deficient cerebral myelination during early development (6). It is important to note that without dietary supplementation, the levels of vitamin $B_{6}$ in certain population groups may fall below that which is required to maintain a healthy state. Pregnant women $(7,8)$, alcoholics $(9,10)$, and women taking oral contraceptives (11) are among the population groups which appear to have low levels of vitamin $B_{6}$. Patients undergoing therapy with certain drugs such as isoniazid (5) and penicillamine (12), which react with pyridoxal 5 '-phosphate (pyridoxal-P), ${ }^{3}$ have

\footnotetext{
${ }^{1}$ Present address: Department of Chemistry, University of California, Berkeley, Calif.

${ }^{2}$ To whom inquiries regarding this work should be addressed.

${ }^{3}$ Abbreviations used: AP, a solution containing a deproteinized plasma sample which has been adjusted to $\mathrm{pH} 7.8$; apo-DSD, D-serine apodehydratase; AU, absorbance unit; BSA, bovine serum albumin;
}

been reported to suffer from abnormalities associated with vitamin $B_{6}$ deficiency, which are reversed when their diet is supplemented with pyridoxine.

The availability of convenient and reliable methods for determining vitamin $\mathrm{B}_{6}$ nutrition would facilitate studies of the molecular basis for abnormalities characteristic of inadequate vitamin $B_{6}$ nutrition. Such assays also would aid in diagnosis of the need for dietary supplementation with pyridoxine prior to the onset of clinical symptoms and irreversible damage. Plasma levels of pyridoxal-P have been shown to be a reliable measure of vitamin $B_{6}$ nutrition in laboratory animals and humans (13-17). Up to now, however, the most reliable and convenient assay for the concentration of pyridoxal-P in plasma has been based upon the extent of reconstitu-

DSD, D-serine dehydratase; DTT, dithiothreitol: Hepps, $N$-2-hydroxyethylpiperazine- $N^{\prime}-3$-propanesulfonic acid; LDH, lactic dehydrogenase; PMSF, phenylmethanesulfonylfuoride; pyridoxal-P, pyridoxal 5'-phosphate. 
tion of the activity of tyrosine apodecarboxylase $(9,18-20)$. Unfortunately, the tyrosine decarboxylase assays are discontinuous assays which require measurement of radiochemically labeled $\mathrm{CO}_{2}$ released in the enzymically catalyzed reaction. In this work, we report a simpler continuous spectrophotometric assay for plasma levels of pyridoxal-P which involves reconstitution of $D$-serine apodehydratase (apo-DSD), by the pyridoxal-P present in a sample, and determination of the activity of the reconstituted enzyme formed from the rate of enzymically catalyzed conversion of D-serine to pyruvate in an LDHcoupled assay.

\section{METHODS}

Materials. Dithiothreitol (DTT), L-cysteine, ribonuclease (bovine pancreas, A grade), deoxyribonuclease (bovine pancreas, B grade), and bovine serum albumin (BSA, crystallized A grade) were obtained from Calbiochem. Phenylmethanesulfonylfluoride (PMSF) was from Eastman. N-2Hydroxyethylpiperazine - $N^{\prime}$ - 3 - propanesulfonic acid (Hepps), D-serine, and lactic dehydrogenase (LDH, type I: crude) were from Sigma. The Hepps buffers used in this work were prepared by partial neutralization of solutions of Hepps with $\mathrm{KOH}$ so that the indicated $\mathrm{pH}$ values and total final concentrations of buffer were obtained. $\mathrm{NaOH}$ should not be substituted for $\mathrm{KOH}$ in the preparation of these buffers, since sodium ion inhibits reconstitution of the enzyme. Prior to use the LDH was dialyzed against $300 \mathrm{vol}$ of $0.1 \mathrm{M}$ Hepps buffer, $\mathrm{pH}$ 7.5 , for $24 \mathrm{~h}$ with one change of buffer. BSA was acetylated according to the procedure of Epstein and Goldberger (21). Ammonium sulfate (ultrapure, enzyme grade) was from Schwarz/Mann. All other chemicals used were reagent grade. The distilled water supplied to the laboratory was passed through a Barnstead deionizer and redistilled in an all-glass Corning AG-2 still.
Protein concentrations and units of $\mathrm{D}$ serine dehydratase (DSD) at $25^{\circ} \mathrm{C}$ were determined as described previously (22).

DSD was isolated from the $\mathrm{C} 6$ mutant of Escherichia coli (ATCC 25842) by a procedure similar to that of Dowhan and Snell (23). A more easily obtainable, crude form of DSD was also found to be adequate for use in determinations of pyridoxal-P and its preparation will be described here. C6 $E$. coli $\mathrm{K} 12$ cells were reisolated and grown as reported previously (22). Deoxyribonuclease and ribonuclease $(1 \mathrm{mg}$ each per 1 liter of suspension) were added to 1 $\mathrm{kg}$ of cell paste which had been suspended in an equal volume of $0.01 \mathrm{M}$ potassium phosphate buffer, $\mathrm{pH}$ 7.2. The suspension was then cooled to $4^{\circ} \mathrm{C}$ and the cells were disrupted by two passages through a Gaulin homogenizer at $900 \mathrm{psi}$. The $43,000 \mathrm{~g}$ (1 h) supernatant solution from the cell homogenate was adjusted to $\mathrm{pH} 6$ with $10 \mathrm{~N} \mathrm{KOH}$ and cooled to $13^{\circ} \mathrm{C}$. Nucleic acids were precipitated by addition (over 20 min with stirring) of $2 \mathrm{ml}$ of $2 \%$ aqueous protamine sulfate (at $\mathrm{pH}$ 5.0) per milligram of supernatant protein. After another $5 \mathrm{~min}$ of stirring, the solution was cooled rapidly to $4^{\circ} \mathrm{C}$ and the precipitate removed by centrifugation at $15,000 \mathrm{~g}$ for $1 \mathrm{~h}$. Protein was precipitated from the solution at $4^{\circ} \mathrm{C}$ by the addition (with stirring over $1 \mathrm{~h}$ ) of saturated ammonium sulfate $\left(4^{\circ} \mathrm{C}\right)$ to $56.6 \%$ saturation. After another $\mathbf{3 0} \mathrm{min}$ of stirring at $4^{\circ} \mathrm{C}$, the precipitated protein was removed by centrifugation $(15,000 \mathrm{~g}$ for 70 min) and dissolved in a minimum volume of $0.01 \mathrm{M}$ potassium phosphate, $\mathrm{pH} 7.2$. The $\mathrm{pH}$ of the resulting solution was adjusted to $\mathrm{pH} 7.0$ with $1 \mathrm{M} \mathrm{K}_{2} \mathrm{HPO}_{4}$ and the solution diluted with $0.01 \mathrm{M}$ potassium phos-

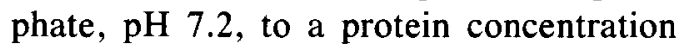
of $40 \mathrm{mg} / \mathrm{ml}$. An equal volume of acetone at $-70^{\circ} \mathrm{C}$ (dry ice-ethanol) was added to the diluted solution over a period of $7-10$ min with stirring. Stirring was continued for 5 min at $-10^{\circ} \mathrm{C}$ (ice-ethanol) and the precipitate was removed by centrifugation 
in polypropylene tubes at $30,000 \mathrm{~g}$ for 10 min. Acetone was removed from the supernatant solution at $20^{\circ} \mathrm{C}$ by rapid evaporation on a Buchi rotary evaporator with the condensing coil cooled with circulating ethylene glycol at $-5^{\circ} \mathrm{C}$ and the receiving flask in an ethanol-ice bath at $-10^{\circ} \mathrm{C}$. In order to minimize the time required to evaporate the acetone, no more than $250 \mathrm{ml}$ of protein solution was treated with acetone at one time.

The suspension remaining after evaporation of the acetone was centrifuged for 20 min at $39,000 \mathrm{~g}$ and the supernatant solution adjusted to 60 units $/ \mathrm{ml}$. After cooling this solution to $4^{\circ} \mathrm{C}$, protein was precipitated by addition (with stirring over 15$20 \mathrm{~min}$ ) of sufficient saturated ammonium sulfate $\left(4^{\circ} \mathrm{C}\right)$ so that the final solution was at $56.5 \%$ staturation. The precipitated protein was removed by centrifugation at $15,000 \mathrm{~g}$ for $50 \mathrm{~min}$ and used as crude DSD. The yield was $660 \mathrm{mg}$ of protein with a specific activity of $20-40$ units/mg. Pure DSD was obtained from crude DSD by the following procedure. Crude DSD was dissolved in a minimum volume of $0.01 \mathrm{M}$ potassium phosphate buffer, $\mathrm{pH} 7.8$, and exhaustively dialyzed against $0.01 \mathrm{M}$ potassium phosphate buffer which contained $0.01 \mathrm{M} 2$-mercaptoethanol and $1 \mu \mathrm{M}$ pyridoxal-P. If necessary the dialyzed solution was clarified by centrifugation for $20 \mathrm{~min}$ at $40,000 \mathrm{~g}$, and subjected to DEAEcellulose chromatography according to step 8 of the procedure of Dowhan and Snell (23). The fractions highest in DSD activity were combined and concentrated to 1000 units $/ \mathrm{ml}$ by ultrafiltration. The resulting solution was diluted to 675 units $/ \mathrm{ml}$ with a buffer such that the final solution was $0.1 \mathrm{M}$ phosphate, $1 \mathrm{mM}$ DTT, and $5 \mu \mathrm{M}$ pyridoxal-P, $\mathrm{pH}$ 7.8. Saturated ammonium sulfate was added dropwise with stirring to the enzyme solution at room temperature so that the final saturation $\left(4^{\circ} \mathrm{C}\right.$ conditions) was $27 \%$. If no signs of turbidity were evident, the ammonium sulfate was added to a maximum of $30 \%$ saturation. The resulting solution was allowed to stand in the dark at $4^{\circ} \mathrm{C}$ until crystallization was complete. One recrystallization is usually required to bring the specific activity up to that of pure enzyme (150-160 units/mg). Recrystallized enzyme $(85 \mathrm{mg})$ was stored at $4^{\circ} \mathrm{C}$ in the dark under $0.1 \mathrm{M}$ potassium phosphate buffer, pH 7.0-7.2, which contained 1 InM DTT, $10 \mu \mathrm{M}$ pyridoxal-P, and ammonium sulfate at $50 \%$ saturation.

Resolution of crude and pure DSD was performed using a procedure similar to that of Dowhan and Snell (23). Typically, enzyme at $10-20 \mathrm{mg}$ protein $/ \mathrm{ml}$ in $0.1 \mathrm{M}$ potassium phosphate buffer, $\mathrm{pH} 7.8$, was dialyzed against $100 \mathrm{vol}$ of resolving buffer. Sufficient resolving buffer for resolution was prepared by adding prior to initiation of the resolution procedure solid cysteine (to $0.5 \mathrm{M}$ ) and DTT (to $1 \mathrm{~mm}$ ) to a solution consisting of $0.4 \mathrm{M}$ imidazole and $10 \mathrm{~mm}$ EDTA which had been adjusted to $\mathrm{pH} 6.5$ by the addition of solid citric acid. The $\mathrm{pH}$ of the resulting solution was then readjusted to 6.5 by the addition of concentrated $\mathrm{KOH}$, and was deaerated by bubbling nitrogen through the solution for $30 \mathrm{~min}$ with stirring. The deaerated solution was stored in a stoppered bottle under argon until used in dialysis. Just prior to use in dialysis, each portion of resolving buffer was made $0.1 \mathrm{mM}$ PMSF by addition of $85 \mathrm{~mm}$ PMSF in ethanol. This procedure, which presumably inactivated serine proteases, markedly increased the yield and stability of apoenzyme from crude DSD. Dialysis was carried out in a cylinder fitted with a two-hole stopper to allow entrance and exit of nitrogen which was bubbled through the resolving buffer during dialysis. Care was taken to ensure that the dialysate was well stirred and that the dialysis sac rotated freely. The resolving buffer was changed every $6 \mathrm{~h}$ until the desired degree of resolution was obtained, as measured by comparing the residual activity of the enzyme to that generated after incubating 
the enzyme with $1 \mu \mathrm{M}$ pyridoxal-P. Between 20 and $30 \mathrm{~h}$ of dialysis was usually required to obtain enzyme which had an activity less than $0.1 \%$ that of fully reconstituted enzyme. Resolved enzyme was separated from the resolving buffer by gel filtration on a column of Sephadex G-25 (coarse) which was eluted with $0.1 \mathrm{M}$ potassium phosphate, $1 \mathrm{~mm}$ DTT, pH 7.8. After elution from the Sephadex column a sevenfold excess by weight of acetylated BSA was added to the pure apo-DSD. No acetylated BSA was added to the crude apo-DSD. In both cases the protein solution was diluted with distilled water about sevenfold and lyophilized.

Withdrawal and treatment of blood. Blood $^{4}$ was withdrawn from normal volunteers by venipuncture after an overnight fast, and collected in a syringe or vacutainer containing sufficient $200 \mathrm{~mm}$ EDTA disodium salt to yield a final EDTA concentration of $2 \mathrm{mM}$ in the sample. The plasma was separated from the whole blood by centrifugation and deproteinized by vigorously mixing 1 vol of $3 \mathrm{~N} \mathrm{HClO}_{4}$ with 9 vol of plasma on a Vortex mixer. After 10 min at room temperature, the precipitated protein was removed by centrifugation. An aliquot $(\geq 0.10 \mathrm{ml}$ ) of deproteinized plasma was then mixed with an equal volume of a solution consisting of $0.1 \mathrm{M}$ Hepps, $50 \mathrm{~mm}$ EDTA which had been adjusted to $\mathrm{pH} 8.75$ with $10 \mathrm{~N} \mathrm{KOH}$. The resulting solution was incubated in an ice bath for $45 \mathrm{~min}$ and the precipitated $\mathrm{KClO}_{4}$ removed by centrifugation. The supernatant solution (AP), which was at $\mathrm{pH} 7.8$, was stored in the dark.

Assays for pyridoxal-P involved a twostep procedure wherein apoenzyme was reconstituted by a sample containing pyridoxal-P and then assayed. Approximately

\footnotetext{
${ }^{4}$ Determination of the plasma concentration of pyridoxal-P from a single enzymic assay can be accomplished with a $0.4-\mathrm{ml}$ sample of blood.
}

$2.5 \mathrm{mg}$ of lyophilizate ${ }^{5}$ from pure apo-DSD or 6.5 mg lyophilizate ${ }^{5}$ from crude apo-DSD was dissolved in $1 \mathrm{ml}$ of a buffer consisting of $0.5 \mathrm{M}$ Hepps, $50 \mathrm{~mm}$ EDTA, $5 \mathrm{~mm}$ DTT, 1 mM PMSF, 10\% ethanol, at pH 7.8. Insoluble material was removed by centrifugation and, when necessary, the resulting solution was diluted with additional buffer in order to adjust the $A_{280}$ of the solution to 0.20 when pure apo-DSD was used and to 0.42 when crude apo-DSD was used. ${ }^{6}$ To reconstitute the apoenzyme, 100 $\mu$ l of a sample containing pyridoxal-P in AP or in $0.5 \mathrm{M}$ Hepps, pH 7.8, was mixed with $50 \mu 1$ of the solution of apoenzyme and $25 \mu \mathrm{l}$ of $0.5 \mathrm{M}$ Hepps, pH 7.8, which in some cases contained a known amount of added pyridoxal-P as a calibration standard. After $15 \mathrm{~min}$ at $37^{\circ} \mathrm{C}, 100 \mu \mathrm{l}$ of the reconstitution mixture was removed and

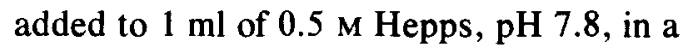
cuvette at $25^{\circ} \mathrm{C}$. The assay was initiated after $15 \mathrm{~min}$ at $25^{\circ} \mathrm{C}$ by the addition of $50 \mu \mathrm{l}$ of a solution consisting of $5 \mathrm{~mm} \mathrm{NADH,}$ $0.22 \mathrm{M}$ D-serine, 350 units $\mathrm{LDH}$ activity $/ \mathrm{ml}$, in $0.5 \mathrm{M}$ Hepps, $\mathrm{pH} 7.8$. The decrease in absorbance at $340 \mathrm{~nm}$ was followed on a recording spectrophotometer for at least 0.1 absorbance unit, and the slope equated to the activity of the enzyme. Standard solutions containing known amounts of pyridoxal-P for calibration of the assay were prepared by dilution of a stock solution of pyridoxal-P in $0.1 \mathrm{M}$ sodium phosphate, $\mathrm{pH}$

\footnotetext{
${ }^{5}$ The lyophilizate consists mainly of salts and is less than $10 \%$ protein.

${ }^{6}$ These absorbance values correspond to apoenzyme concentrations of $0.6 \mu \mathrm{M}$ as determined by titration with pyridoxal-P. The possible presence of oxidized DTT in samples of apo-DSD made it impractical to calculate the operational normality of the apoenzyme solution from its absorbance. A solution of apo-DSD will respond well in the assays for plasma pyridoxal-P if the observed enzymic activity increases by 10 - to 20 -fold when the concentration of pyridoxal-P is increased from $15 \mathrm{nM}$ (limiting pyridoxal-P) to $1 \mu \mathrm{M}$ (excess pyridoxal-P) in the reconstitution mixture.
} 
7.0 , wherein the molar absorptivity of pyridoxal-P is $4900 \mathrm{M}^{-1} \mathrm{~cm}^{-1}$ at $388 \mathrm{~nm}$ (24).

\section{RESULTS AND DISCUSSION}

The assays for pyridoxal-P that are described in this work consist of incubating samples containing pyridoxal-P with excess apo-DSD in $0.5 \mathrm{M} \mathrm{Hepps,} \mathrm{pH} 7.8$, at $37^{\circ} \mathrm{C}$ for $15 \mathrm{~min}$, and then transferring an aliquot of the incubation mixture to a cuvette for determination of its DSD activity. DSDcatalyzed conversion of $\mathrm{D}$-serine to pyruvate was monitored using an LDH-coupled assay similar to that described by Dowhan and Snell (23), wherein depletion of NADH upon its reaction with pyruvate in the $\mathrm{LDH}$ catalyzed reaction was followed in a continuous spectrophotometric assay at $340 \mathrm{~nm}$. In these assays, the decrease in absorbance was linearly dependent on time for about 0.9 absorbance unit, and the rate of change of absorbance was not altered by increasing the concentration of LDH.

Figure 1 shows the linear dependence of enzymic activity on the amount of pyridoxal-P in the assay cuvette with freshly prepared pure apo-DSD and with crude apo-DSD after several months of storage as a lyophilized powder at $4^{\circ} \mathrm{C}$. Since apoDSD combines with pyridoxal-P with a $1: 1$ stoichiometry to form active enzyme $(25,26)$, a comparison of the activity generated per mole of added pyridoxal- $\mathrm{P}^{\boldsymbol{7}}$ with the specific activity of pure holoenzyme under the assay conditions should indicate whether fully active enzyme was formed in the reconstitution reaction. Such a comparison indicated that the holoenzyme generated from freshly prepared pure apo-DSD was $77 \%$ active, whereas holoenzyme generated from the stored crude apoenzyme was only $19 \%$ as active as pure holenzyme. It is unlikely that the low activity observed for reconstituted crude apoenzyme was

\footnotetext{
${ }^{7}$ The product of the slope of each plot in Fig. 1 and the $M_{\mathrm{r}}$ of pyridoxal-P yields this quantity.
}

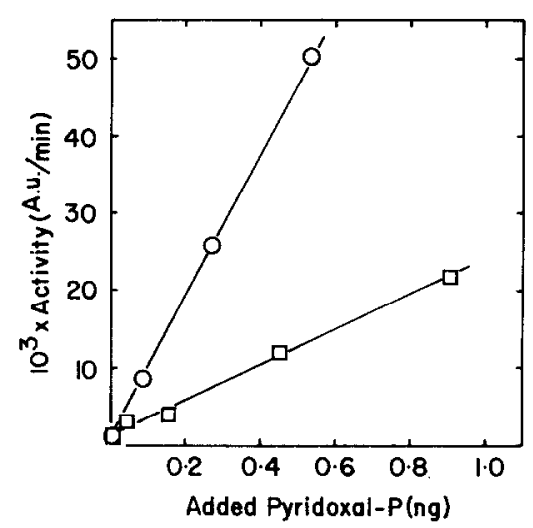

FIG. I Dependence of enzymic activity on the amount of added pyridoxal-P in the assay cuvette. Known amounts of pyridoxal-P were incubated with $170 \mathrm{~nm}$ pure apo-DSD $(O)$ and crude apo-DSD ( $\square$ ) at $37^{\circ} \mathrm{C}$ for $15 \mathrm{~min}$, whereupon $0.1 \mathrm{ml}$ of the incubation Inixture was transferred to a cuvette containing $1 \mathrm{ml}$ $0.5 \mathrm{M}$ Hepps, $\mathrm{pH} 7.8$, at $25^{\circ} \mathrm{C}$. Assays were initiated after $15 \mathrm{~min}$ by the addition of $50 \mu \mathrm{l}$ of a solution consisting of $5 \mathrm{mM} \mathrm{NADH}, 0.22 \mathrm{M}$ D-serine, 350 units $\mathrm{LDH} / \mathrm{ml}$ in $0.5 M$ Hepps, $\mathrm{pH} 7.8$. The decrease in absorbance at $340 \mathrm{~nm}$ was followed on a recording spectrophotometer for at least $0.1 \mathrm{AU}$, and the rate of absorbance change equated to the plotted enzymic activities.

caused by the presence of inhibitors, since the presence of crude apoenzyme did not alter the activity of pure holoenzyme. The possibility that the low activity generated from crude apoenzyme was due to insufficient incubation time with pyridoxal-P was investigated in the studies presented in Fig. 2. Although the yield of regenerated activity is not at its maximal value at 15 min, it is doubtful that the low yicld of activity obtained with the stored crude apoenzyme can be attributed entirely to the 15-min incubation time being too short. It is more likely, that the protein reconstituted from stored crude apoenzyme has a low catalytic activity. Storage of pure apo-DSD for several months also caused a lowering of the specific activity of the regenerated enzyme. As shown in Fig. 1, however, generation of reconstituted enzyme which is $100 \%$ active is not necessary to obtain 


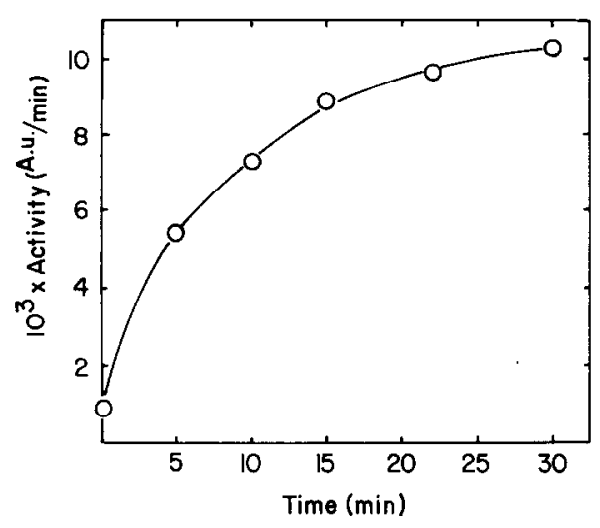

FIG. 2. Time dependence of the reconstitution of crude apo-DSD. Crude apo-DSD at $170 \mathrm{~nm}$ was incubated with $19 \mathrm{~nm}$ pyridoxal-P at $37^{\circ} \mathrm{C}$. $\Lambda t$ the indicated times $0.1-\mathrm{ml}$ samples of the incubation mixture were withdrawn and their enzymic activities determined as described in the legend to Fig. 1.

a linear relationship between enzymic activity and the amount of pyridoxal-P.

Figure 3 illustrates the effect on enzymic activity of incubating crudc apo-DSD with a sample of deproteinized plasma plus known amounts of pyridoxal-P. The net activities plotted in Fig. 3 were obtained by subtracting from the activity observed with the sample, the activity arising from the small amount of unresolved holoenzyme present in apo-DSD. This activity was determined from separate assay of apo-DSD in the absence of plasma. Assay of pure holoenzyme in the presence of plasma indicated that the activity of holoenzyme is not altered significantly by the plasma which is present in the assay. This observation supports the validity of the method used to correct the observed activity for the presence of holoenzyme in the apo-DSD. The two lines in Fig. 3 were obtained from the same sample of plasma. One hour prior to deproteinization pyridoxal-P (12.0 $\mathrm{ng} / \mathrm{ml}$ plasma) was added to the plasma sample that was used to obtain the data for the upper line in Fig. 3. The slope of the plots in Fig. 3 is equal to the proportionality constant (i.e., response factor) between the net activity and the amount of pyridoxal-P present. The amount of pyridoxal-P introduced in the assay cuvette by the sample is obtained by dividing the net activity observed for the sample in the absence of added pyridoxal-P ( $y$-intercepts in Fig. 3) by the response factor for the assay. Division of these values by the volume of plasma (25.7 $\mu \mathrm{l}$ in these determination) in the assay cuvette should yield concentrations of pyridoxal-P in the plasma samples. The assays depicted in Fig. 3 indicate that the plasma sample to which no pyridoxal-P was added contained $14.0 \pm 0.5 \mathrm{ng} / \mathrm{ml}$ pyridoxal-P and the plasma sample that was enriched with pyridoxal-P $1 \mathrm{~h}$ prior to

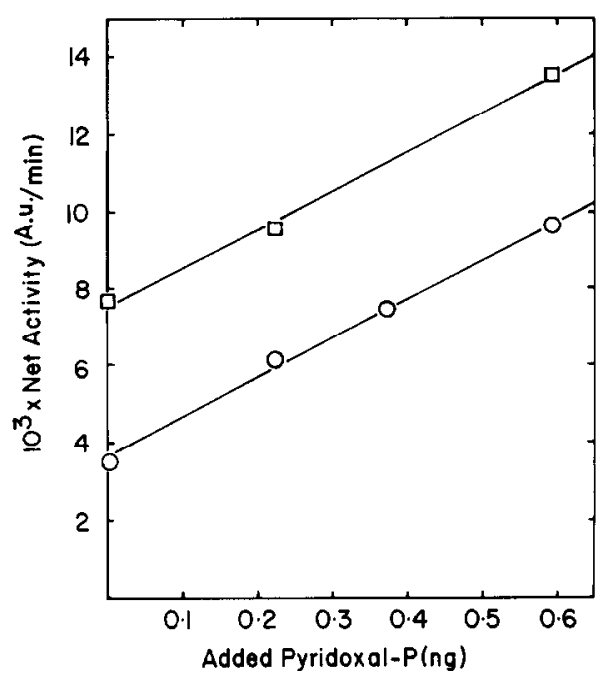

FIG. 3. Dependence of activity on added pyridoxal-P in the assay cuvette in the presence of a plasma sample $(25.7 \mu 1)$. The net activities plotted are differences between observed activities and the activity arising from the unresolved holoenzyme present in the apoDSD. The activity of unresolved holocnzyme $(0.94$ $\times 10^{-3} \mathrm{AU} / \mathrm{min}$ ) was determined by assaying an incubation mixture wherein $0.5 \mathrm{M}$ Hepps, $\mathrm{pH} 7.8$, was added in place of the plasma sample. Samples were incubated with apoenzyme and assayed as described in the legend to Fig. 1. The assay cuvettes contained the indicated amounts of added pyridoxal-P plus a plasma sample corresponding to $25.7 \mu \mathrm{l}$ of undiluted plasma $(O)$. The open squares illustrate the effect of enriching the plasma sample with pyridoxal-P (12.9 $\mathrm{ng} / \mathrm{ml}$ ) $1 \mathrm{~h}$ prior to deproteinization. 
deproteinization contained $29.0 \pm 1.1 \mathrm{ng} / \mathrm{ml}$ pyridoxal-P. The difference between these two values corresponds to a $116 \pm 9 \%$ recovery of the added pyridoxal-P. Plasma enriched with pyridoxal-P and allowed to stand at room temperature for $24 \mathrm{~h}$ prior to deproteinization showed a $111 \%$ recovery of the added pyridoxal-P. The 24-h incubation of pyridoxal-P with plasma should have been sufficient time for the added pyridoxal-P to bind plasma proteins. The good recovery (after both 1 and $24 \mathrm{~h}$ ) of the added pyridoxal-P is consistent with the conclusion that all protein bound pyridoxal-P is released during the treatment with perchloric acid. These results contrast somewhat with those of Srivastava and Beutler (27), who observed a $70 \%$ recovery of added pyridoxal-P after it had incubated with plasma for $20 \mathrm{~min}-24 \mathrm{~h}$. Perhaps the difference in recovery of added pyridoxal-P is due to differences in the methods used to deproteinize the plasma sample.

It should be noted that the dependence of the observed activity on the amount of added pyridoxal-P is a function of the volume of plasma present in the incubation mixture, so that the efficiency of the reconstitution reaction decreases with increasing amounts of plasma. This reduction in efficiency may be caused by lowered affinity of apo-DSD for pyridoxal-P in the presence of a component of deproteinized plasma such as chloride ion. ${ }^{8}$ The dependence of the response of the assay to added pyridoxal-P should be taken into account in designing modifications of the assay procedure. Either the same volume of plasma should be used in each set of

\footnotetext{
${ }^{8}$ In a separate study wherein trichloroacetic acid was used for deproteinization, reconstitution of the apoenzyme was observed to be markedly inhibited by trichloroacetate. The presence of this anion also resulted in a nonlinear time dependence of absorbance in the rate assay which made trichloracetic acid unsuitable for deproteinization in this assay.
}

assays or the response of the assay to added pyridoxal-P should be determined for each assay wherein a different volume of plasma is used. Using this approach, the determined plasma pyridoxal-P concentration was found to be independent of the volume of plasma used in the analysis.

Although the response factor associated with the assay varies with the volume of plasma used, it does not appear to vary significantly among individuals. Plasma from a group of five volunteers exhibited response factors which were within $3 \%$ (standard deviation) of each other. Thus, the response factor and the activity associated with the unresolved holoenzyme in the apo-DSD need only be determined once each time a new solution of apo-DSD is prepared. The concentration $(P)$ of pyridoxal-P in an individual sample of plasma can then be determined from the measured activity with a plasma sample using the relationship.

$$
P=(A-B) / R V,
$$

where $A$ and $B$ are the activities observed with the plasma sample and a blank containing no plasma, $V$ is the volume of undiluted plasma in the assay cuvette, and $R$ is the response factor for the assay, which can be determined from the increase in activity produced by adding a known amount of pyridoxal-P to plasma.

In addition to the convenience and rapidity of the pyridoxal- $P$ assay reported in this work, only $0.4 \mathrm{ml}$ of blood is required to determine a plasma pyridoxal-P concentration. The present assay easily can be scaled down, however, so as to require less than $0.1 \mathrm{ml}$ of blood by using smaller cuvettes in the spectrophotometric assay. Furthermore, the reagents used in the assay are reasonably stable. The solutions containing the substrates and $\mathrm{LDH}$ can be stored at $4^{\circ} \mathrm{C}$ for at least 10 days with no detectable change in the response of the assay to added pyridoxal-P. Solutions 
of crude apo-DSD could be stored for 4 days at $4^{\circ} \mathrm{C}$ and used in the assay with no change in the response of the assay to added pyridoxal-P. ${ }^{9}$

\section{REFERENCES}

1. Rinehart, J. F., and Greenberg, L. D. (1949) Amer. J. Pathol. 25, 481-491.

2. Heeley, A., Pugh, R. J. P., Clayton, B. E., Shepherd, J., and Wilson, J. (1978) Arch. Dis. Child. 53, 794-802.

3. Lerner, A. M., DeCarli, L. M., and Davidson, C. S. (1958) Proc. Soc. Exp. Biol. Med. 98, 841-843.

4. Hines, J. D. (1976) Sem. Hematol. 13, 133-140.

5. Carlson, H. B., Anthony, E. M., Kussell, W. F., Jr., and Middlebrook, G. (1956) N. Engl. J. Med. 255, 118-122.

6. Kurtz, D. J., Levy, H., and Kanfer, J. N. (1972) J. Nutr. 102, 291-298.

7. Brophy, M. H., and Siiteri, P. K. (1975) Amer. J. Obstet. Gynecol., 1075-1079.

8. Lumeng, L., Cleary, R. E., Wagner, R., Yu, P. L., and $\mathrm{Li}, \mathrm{T}$. K. (1976) Amer. J. Clin. Nutr. 29, $1376-1383$.

9. Lumeng, L., and Li, T. K. (1974) J. Clin. Invest. 53, 693-704.

10. Hines, J. D., and Cowan, D. H. (1970) N. Engl. J. Med. 283, 441-446.

${ }^{9}$ Solutions of pure apo-DSD were less stable. When these solutions were used, small changes $(\sim 5 \%)$ in the response of the assay could be detected after the solutions had been kept at $4^{\circ} \mathrm{C}$ at $8 \mathrm{~h}$.
11. Lumeng, L., Cleary, R. E., and Li, T. K. (1974) Amer. J. Clin. Nutr. 27, 326-333.

12. Tu, J. B., Blackwell, R. Q., and Lee, P. F. (1963) J. Amer. Med. Assoc. 185, 83-86.

13. Wachstein, M. J., Kellner, J. D., and Ortiz, J. M. (1960) Proc. Soc. Exp. Biol. Med. 103, 350353.

14. Hamfelt, A. (1967) Clin. Chim. Acta 16, 19-28.

15. Brown, R. R., Rose, D. P., Leklem, J. E., Linkswiler, H., and Anand, R. (1975) Amer. J. Clin. Nutr. 28, 10-19.

16. Lumeng, L., Ryan, M. P., and Li, T. K. (1978) J. Nutr. 108, 545-553.

17. Shane, B., and Contractor, S. F. (1975) Amer. J. Clin. Nutr. 28, 739-747.

18. Hamfelt, A. (1967) Scand. J. Clin. Lab. Invest. 20, 1- 10.

19. Chabner, B., and Livingston, D. (1970) Anal. Biochem. 34, 413-423.

20. Bhagavan, H. N., Koogler, J. M., Jr., and Coursin, D. B. (1976) Int. J. Vitamin Nutr. Res. 46, 160-164.

21. Epstein, C. J., and Goldberger, R. F. (1964) J. Biol. Chem. 239, 1087-1089.

22. Schonbeck, N. D., Skalski, M., and Shafer, J. A. (1975) J. Biol. Chem. 250, 5352-5358.

23. Dowhan, W., Jr., and Snell, E. E. (1970) J. Biol. Chem. 245, 4618-4628.

24. Peterson, E. A., and Sober, H. A. (1954) J. Amer. Chem. Soc. 76, 169-175.

25. Dupourque, D., Newton, W. A., and Snell, E. E. (1966) J. Biol. Chem. 241, 1233-1238.

26. Labow, R., and Robinson, W. G. (1966) J. Biol. Chem. 241, 1239-1243.

27. Srivastava, S. K., and Beutler, E. (1973) Biochim. Biophys. Acta 304, 765-773. 